\title{
AQUACULTURAL INTEGRATION IN RECREATIONAL TOURISM: FEATURES OF DEVELOPMENT AND MANAGEMENT OF COASTAL TERRITORIES
}

\author{
Taras Melikh1, Dmytro Voit ${ }^{2}$, Dariia Archybisova³
}

\begin{abstract}
Tourism has been growing and diversifying in recent years to become one of the fastest growing sectors of the economy in the world. Modern tourism is closely linked to economic development and is embracing an increasing number of new destinations. Such dynamics have transformed tourism into a key driver of socioeconomic progress. As for recreational tourism as one of the key species, it not only covers most of the related industries directly or indirectly, including transport, construction, trade, catering, agriculture, housing and communal services, culture, art, sports, etc., but also stimulates their development. The focus of recreational tourism on the sea and ocean coasts has expanded the range of tourism services. Aquaculture, which is becoming more relevant in the context of ecosystem conservation, is one of these areas of activity. Since aquaculture and tourism require certain requirements for water quality and the environment, there is an inevitable conflict of interest between entrepreneurs. And as research has shown, such conflicts have arisen in many countries. It has been found that solving this issue may not be the same for everyone. Only individual management, strategic planning and continuous monitoring will allow the effective development of coastal areas and profit for the country. Independent research conducted by the Scottish Research Forum found no evidence of a negative relationship between aquaculture and recreation. In many cases, aqua farms are of cognitive and gastronomic interest to tourists. The study also does not consider the development of aquaculture to be incompatible with tourism, but on the contrary it is an integrating process. Both industries are important to the economies of the countries, so in every territory where aquaculture and recreation can be mutually beneficial, a balance must be struck between them. The aim of the study is to analyze the specific aspects of aquaculture in Ukraine and in the world. The main objectives of our research are: to explore the role and importance of aspects of the introduction of recreational tourism in aquaculture; to analyze the current state of tourism in the world and its economic indicators; to identify the problems of intensification of recreational tourism in the coastal regions of the world; to offer the own vision of the prospects of integrating aquaculture into recreational tourism. Research methods. To achieve this goal there are used general scientific and special research methods in the work, such as: statistical method is for systematizing economic and statistical information on the development of tourism and aquaculture; methods of analysis and synthesis are for studying the functioning of aquaculture in general and its individual aspects; regional method is for studying the functioning of the industry in regional development; method of economic analysis is implemented in identifying trends, patterns and prospects of tourism and aquaculture.
\end{abstract}

Key words: tourism, recreation, recreational services, aquaculture, coastal management, development of the region.

JEL Classification: Z32, Q22, R11

\section{Introduction}

Everyyear, tourism in the world reaches a leading position in the structure of GDP and significantly outperforms other branches of intangible production. The decisive role of tourism is its tangible contribution to the development of the country's economy. Active travel tourism has a great impact on geographical space, this effect is evident on all elements located in a certain territory and has certain effects

\footnotetext{
Corresponding author:

${ }^{1}$ Alfred Nobel University, Ukraine.

${ }^{2}$ International University of Business and Law, Ukraine.

${ }^{3}$ Admiral Makarov National University of Shipbuilding, Ukraine.
}

that can be economic, social and environmental. The latter are at the forefront of discussion today as there are acute problems with the conservation of terrestrial and aquatic ecosystems. Therefore, the main focus of tourism for the previous five years has become recreational. Recreation in an increasingly global development is becoming increasingly important. It is a leading form of economic growth for many countries and the improvement of the 
lives of local communities. Recreational areas near water bodies are one of the most important opportunities to meet the growing demand for recreation.

The following statistics show the extent of recreation: $-20 \%$, that is, $1 / 5$ of the entire population of the world, annually takes part in recreational activities and trips; $-40-55 \%$ of the population of major cities in the world travel outside cities for recreational purposes on weekends;

- recreational spending in economically developed countries is 2.3 times higher than spending on clothing and footwear and $18 \%$ higher than the cost of purchasing food products (Pokolodna, 2012).

In recent years, about $51 \%$ of international tourist trips are made for leisure and recreation, with business and professional purposes accounting for $15 \%$, and $27 \%$ for specific purposes: visiting friends and relatives, pilgrimage, medical treatment and more.

Recreational tourism development has a leading role in the management of recreational resources, especially in the coastal areas where a new branch of agriculture aquaculture - has been developing recently. On the one hand, recreation is a competitor in aquaculture, and on the other hand, it can become a driver of production development. The development of tourism in the context of enhancing aquaculture will create additional economic, social and environmental value and will be a facilitator of the multifaceted use of coastal zones.

\section{Analysis of the economic and ecological effect of tourism on coastal aquaculture}

There are 15 countries in the world that specialize in travel services, where tourism revenues often exceed in many times the export of goods, and in 45 countries, tourism revenue exceeds $1 / 4$ of exports. The functioning of business entities in the field of tourism is closely linked to the development of the economy, or affects the development of 32 branches of the national economy. Today's preview from HowMuch.net highlights the countries where tourists spend the most money. The location has been changed based on the costs that come from the latest World Tourism Organization data (Figure 1) (Global Report on Food Tourism).

As we can see, the top is headed by countries that have access to the seas or oceans (Table 1).

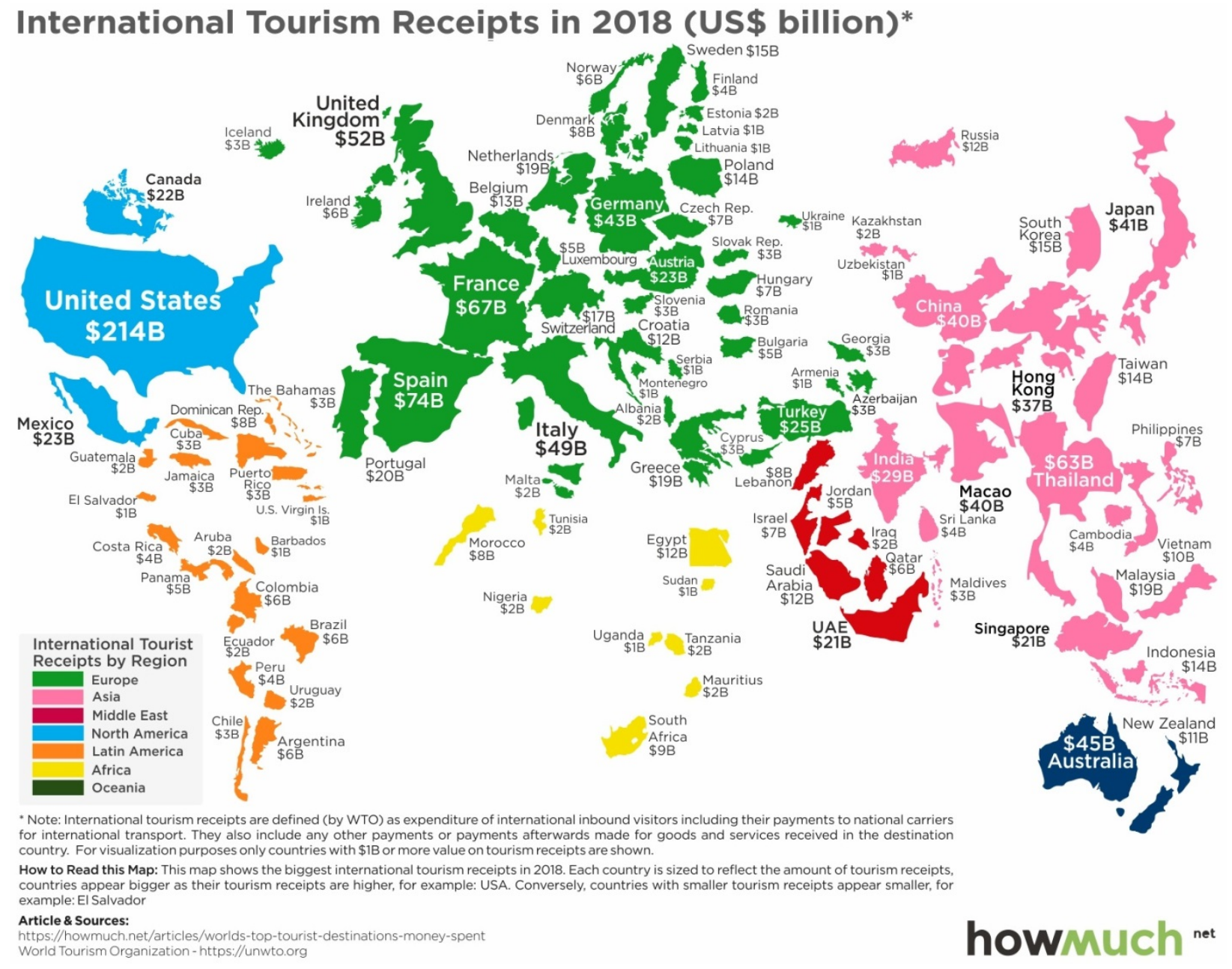

Figure 1. Top countries by tourist spending (Mapped: Top Countries by Tourist Spending) 
Table 1

The most popular tourist destinations by country (Global Report on Food Tourism)

\begin{tabular}{|c|c|c|c|c|c|}
\hline Country & 2018 Spending & 2018 Arrivals & Country & 2017 Spending & 2017 Arrivals \\
\hline 1. The USA & $\$ 214.5 \mathrm{~B}$ & $79.6 \mathrm{M}$ & 1. The USA & $\$ 210.7 \mathrm{~B}$ & $74.8 \mathrm{M}$ \\
\hline 2. Spain & $\$ 73.8 \mathrm{~B}$ & $82.8 \mathrm{M}$ & 2. Spain & $\$ 68 \mathrm{~B}$ & $81.8 \mathrm{M}$ \\
\hline 2. France & $\$ 67.4 \mathrm{~B}$ & $89.4 \mathrm{M}$ & 3. France & $\$ 60.7 \mathrm{~B}$ & $86.9 \mathrm{M}$ \\
\hline 4. Thailand & $\$ 63 \mathrm{~B}$ & $38.3 \mathrm{M}$ & 4. Thailand & $\$ 57.5 \mathrm{~B}$ & $35.4 \mathrm{M}$ \\
\hline 5. UK & $\$ 51.9 \mathrm{~B}$ & $36.3 \mathrm{M}$ & 5. UK & $51.2 \mathrm{~B}$ & $37.7 \mathrm{M}$ \\
\hline 6. Italy & $\$ 49.3 \mathrm{~B}$ & $62.1 \mathrm{M}$ & 6. Italy & $\$ 44.2 \mathrm{~B}$ & $58.3 \mathrm{M}$ \\
\hline 7. Australia & $\$ 45 \mathrm{~B}$ & $9.2 \mathrm{M}$ & 7. Australia & $\$ 41.7 \mathrm{~B}$ & $8.8 \mathrm{M}$ \\
\hline 8. Germany & $\$ 43 \mathrm{~B}$ & $38.9 \mathrm{M}$ & 8. Germany & $\$ 39.8 \mathrm{~B}$ & $37.5 \mathrm{M}$ \\
\hline 9. Japan & $\$ 41.1 \mathrm{~B}$ & $31.2 \mathrm{M}$ & 9. Macao (SAR) & $\$ 35.6 \mathrm{~B}$ & $17 \mathrm{M}$ \\
\hline 10. China & $\$ 40.4 \mathrm{~B}$ & $62.9 \mathrm{M}$ & 10. Japan & $\$ 34.1 \mathrm{~B}$ & $28.6 \mathrm{M}$ \\
\hline
\end{tabular}

The countries of Western Europe are distinguished in the world by the highest level of exploitation of recreational resources, their most efficient use and provision of recreational services. The countries of Europe are the most recreationally attractive in the world. About $60 \%$ of all tourists on our planet are involved in its natural, cultural, historical and ethnic diversity. Europe is like a whole world in miniature. Traditional leaders in terms of tourist visits to Europe are France (74.5 million people), Spain (53.6 million people), and Italy (41.2 million people), the United Kingdom (24.9 million people), Germany (18.9 million people), Greece (12.5 million people), which together account for $78 \%$ of the world's revenue. At the same time, we can see that the proportion of less developed and developing countries is gradually increasing every year. On average, one tourist brings about $\$ 870$ to the country, however, each country as an agent of the world recreational market has its own specificity (Global Report on Food Tourism).

Each coastal country has the Exclusive Economic Zones (EEZs) that can extend up to $200 \mathrm{~km}$ offshore. Legal mechanisms and investment incentives are often introduced in these regions to privatize and develop these marine areas for aquaculture and other industrial purposes. The geography of aquaculture concentration is shown in Figure 2. This commercial exploitation will go beyond sub-national (state or provincial) regulation.

The World Tourism Organization reports that in the first half of 2019 the number of international tourists from January to June in the world amounted to 671 million people. It is noted that this figure is 30 million more than in the same period in 2018, which is an increase of $4.4 \%$. The flow of tourists to the Middle East countries increased by $8 \%$, by $6 \%$ to Asia and the Pacific region. Tourists arrived in the European

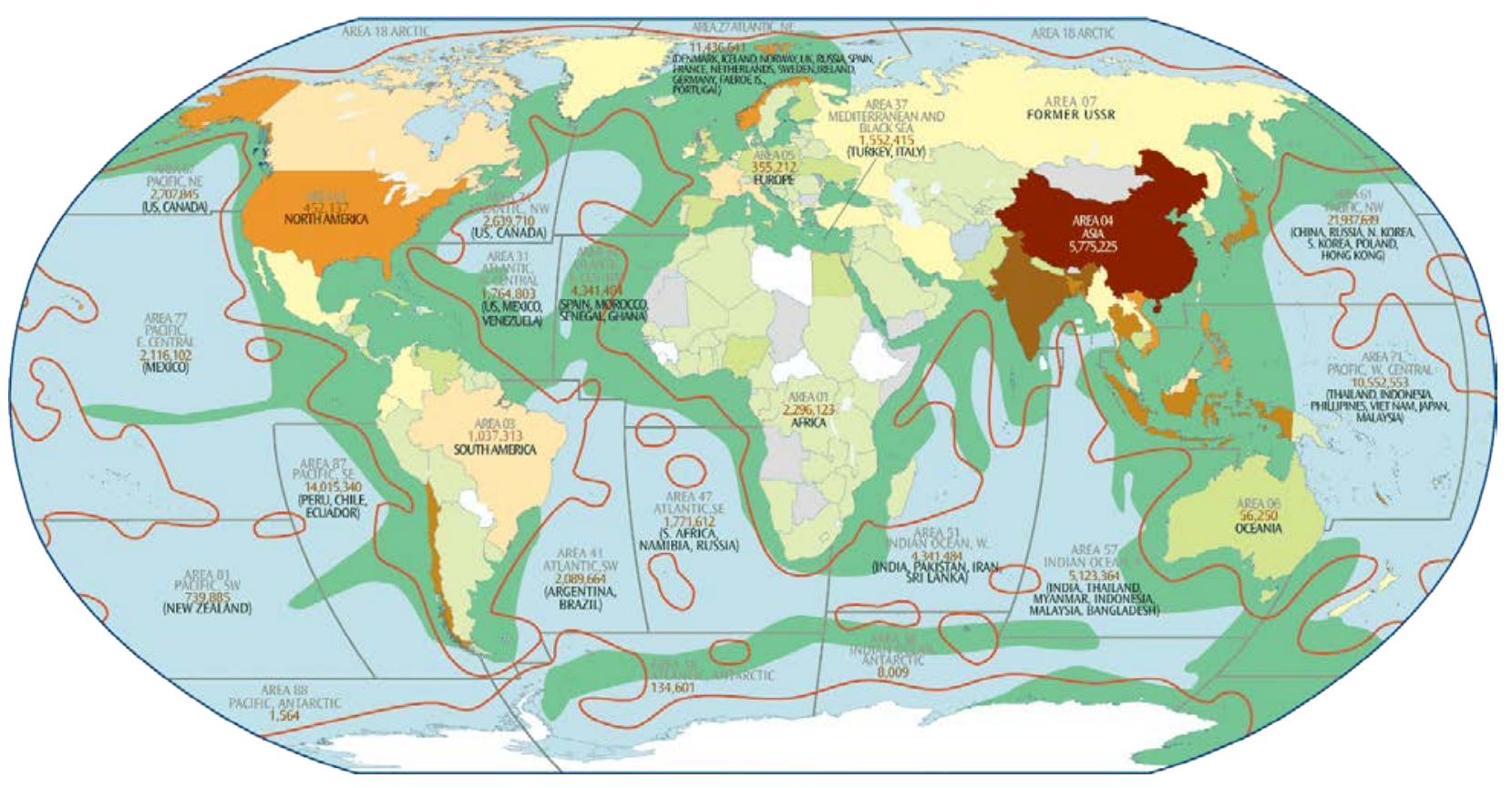

Figure 2. Global Aquaculture and Fisheries Map (Fishing \& Aquaculture) 


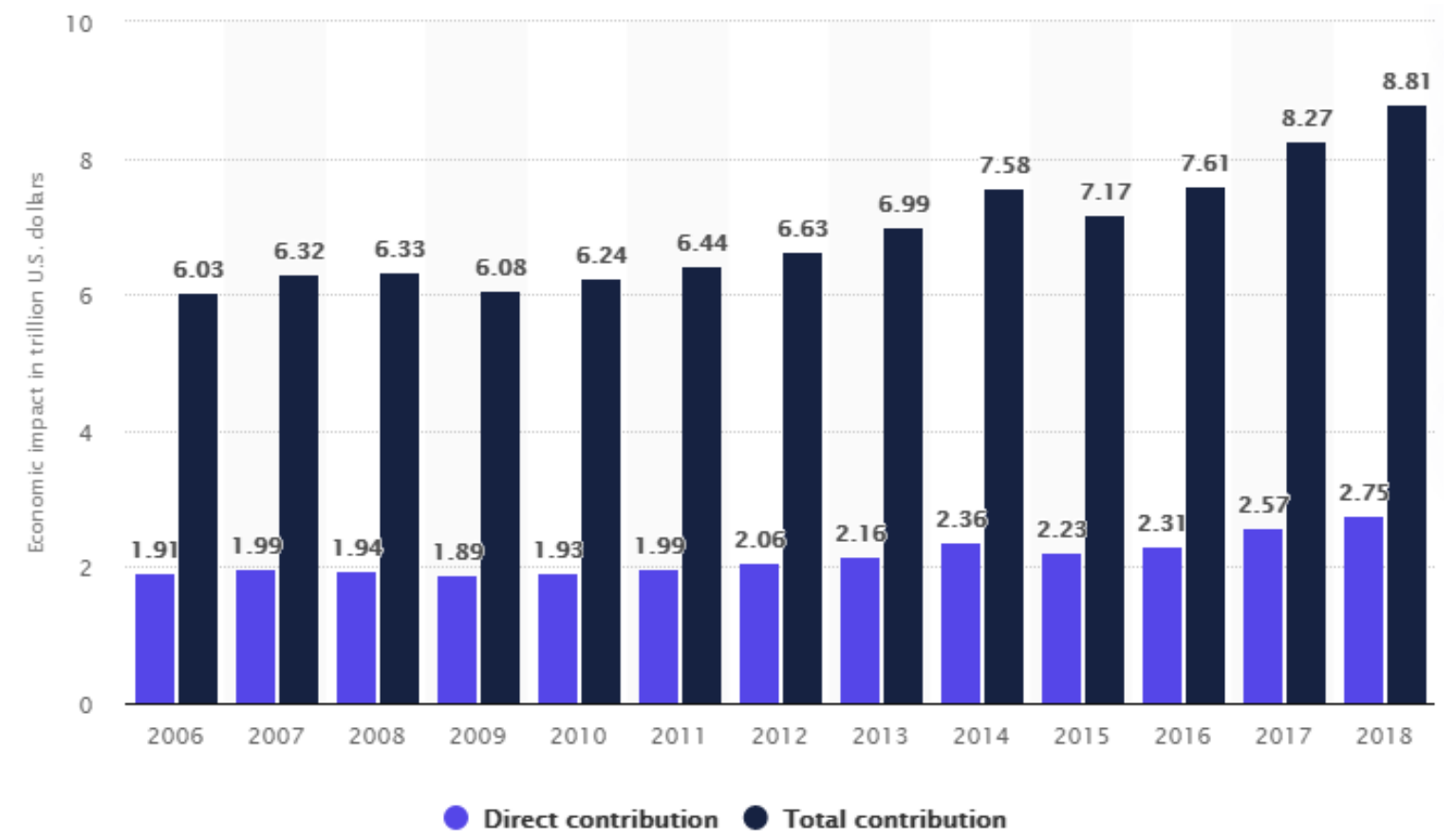

Figure 3. The economic contribution of travel and tourism to GDP worldwide 2006-2018 (Global No.1 Business Data Platform)

countries in the first six months of this year by $4 \%$ more than in the same period in 2018. North America has seen a $2 \%$ increase in tourists and $1 \%$ in Central America. In South America, the number of tourists decreased by $5 \%$, including due to a decrease in outbound trips from Argentina, which affected neighboring destinations. In Africa, the number of international arrivals increased by $3 \%$. At the same time, North Africa (+9\%) continues to show steady results, while the arrival of sub-Saharan arrivals is close to zero. In the Middle East in 2019 there was recorded growth of $+8 \%$. These statistics show the direct and overall economic impact of travel and tourism on the world economy from 2006 to 2018 . The direct economic contribution of travel and tourism was about $\$ 2.75$ trillion in 2018 (Figure 3) (The Global Report on Food Tourism).

But the constant movement of tourists has negative consequences, especially for coastal regions. As for water resources, high synergies between tourism and industrial aquaculture can be expected. In addition, the regular stay of tourists in controlled areas (aqua farms) can help to reduce or eliminate poachers and facilitate the detection of illegal fishing. On the other hand, inexperienced tourists can cause significant degradation of the region's biosystem environment. For example, many studies have pointed to the damage done by divers in sensitive coral reef areas. Preventing this harm can be achieved by setting the maximum number of tourists for the area and ensuring that diving masters and nonprofessional divers are properly trained in best practices and possible harms related to this activity.

\section{Experience of advanced countries} of the world of activation of recreational tourism in the context of the development of aquaculture in coastal territories and the possibility of its application in Ukraine

Degradation of ocean ecosystems driven by human activities has led to an increased global interest in the establishment of ocean protected areas. One type of protected area, where all forms of fishing are prohibited, is known as a "marine reserve". Much of the interest in marine reserves is driven by their success in recovering important habitats and increasing species biomass and diversity within the reserve's boundaries. Although reserves can fail to reach their full potential because of the lack of resources for monitoring and enforcement, they are a globally important conservation tool. In addition to these clear conservation benefits, the increases in species population size within reserves can also generate important economic benefits. For example, fisheries benefits can arise through the spillover of adults and/or the export of larvae to surrounding fished areas (Viana, Halpern, Gaines, 2017).

Benefits from tourism can in many cases be far greater than the opportunity cost of foregone fishing. For example, in the Great Barrier Reef annual revenue from tourism is 36 times greater than income from commercial fishing. In the Medes Islands Marine Reserve (Spain) annual revenue from tourism is about 20 times greater than fishing revenue. Potential tourism revenue from marine reserves can be generated directly through user fees or by boosting the tourism economy in the region. Marine Reserves can potentially increase value of all 
business associated with tourism (e.g. hotels, restaurants), especially those dependent on underwater activities (e.g. dive centers). These benefits depend on the location of the reserve as well as the biomass of fish in the water. Reserves located near coastal areas with intense tourism activity and other tourist attractions are likely to have high visitation rates quickly after reserve creation. In such situations, the marine reserve may not be the main draw to the area and often does not require high levels of biomass to attract divers. By contrast, locations where there are no other coastal attractions other than the marine reserve may only attract more experienced divers that are drawn by high levels of fish biomass and diversity. These areas may need to be more spectacular and tied with marketing strategies to attract large numbers of divers, since the reserves will often be competing with diverse diving options around the globe (Viana, Halpern, Gaines, 2017).

In spite of the above data on the economic benefits associated with tourism activities in marine reserves, most spatial planning models consider only fishing and / or environmental benefits, but ignore the tourist benefits. To incorporate the potential benefits of tourism, a bioeconomic model was developed (Viana, Halpern, Gaines, 2017). The model is designed to simulate different designs of marine reserves and their projected impact on fisheries and tourism revenues:

$$
\mathrm{B}_{\mathrm{t}, \mathrm{i}}=\mathrm{B}_{\mathrm{t}-1, \mathrm{i}}+\mathrm{g}^{*} \mathrm{~B}_{\mathrm{t}-1, \mathrm{i}}{ }^{*}\left(1-\mathrm{B}_{\mathrm{t}-1, \mathrm{i}} \mathrm{K}_{\mathrm{i}}\right)-\mathrm{f}_{\mathrm{i}}^{*} \mathrm{~B}_{\mathrm{t}-1, \mathrm{i}}-\mathrm{E}_{\mathrm{t}, \mathrm{i}}+\mathrm{I}_{\mathrm{t}, \mathrm{i}}
$$

Where $B_{t, i}$ is the biomass in year $t$ and patch $i, g$ is the intrinsic growth rate, $K_{i}$ is the carrying capacity, $f_{i}$ is the harvest fraction, $E_{t, i}$ is the emigration from patch $i$ and $I_{t, i}$ is the immigration to patch $i$ from all other patches.

This model may reflect the potential benefits of both services in different tourism and fisheries management scenarios to understand under what conditions marine reserves are part of the optimal solution that maximizes economic benefits. We then analyze the potential tradeoffs between fisheries and tourism's economic benefits to understand the incentives that stakeholders face and situations where conflicts may arise. The expected trade-offs between fisheries and tourism services vary according to different management scenarios. Fisheries revenues are declining with the increase of marine areas. In such cases, if tourist value is ignored, marine reserves are not part of the optimal economic solution. Thus, with perfect fisheries management, it is necessary to introduce tourism services to ensure that marine reserves are part of an optimal economic solution.

The development of tourism in reserves preserves huge costs for infrastructure maintenance and measures for the conservation of natural complexes and objects at the expense of budgetary funds. Without it, it is impossible to talk about the environmental friendliness of tourism. Thus, studies conducted in the Great Barrier Reef National Park (Australia) have shown that the cost of conserving natural complexes is increasing at the same rate as their degree of exploitation. The park administration lacks \$ 15 million per year, which is paid by tour operators, to eliminate and prevent threats to the nature of the reef, so the state is forced to allocate additional funds. The US economy receives about $\$ 3$ billion annually from tourism related to visiting national parks, but a significant portion of the costs of maintaining their regime and compensating for environmental damage are still borne by the US state budget. Tourism in most protected areas makes one of the major contributions to the growth of national economies in these countries. Thus, tourism is of the utmost importance for the governing bodies of the reserves to fulfill the tasks they have set to meet the requests and interests of the visitors.

Ontario's recreational sector is a major generator of job creation, tax revenue and capital exports. Thus, only tourism in Ontario is the fifth largest export industry, generating CA $\$ 7.1$ billion in provinces. The contribution of tourism to the province's GDP reached CA $\$ 7.2$ billion, exceeding the share of agriculture, mining and forestry.

In Ontario, taxes on the hotel sector now include a retail tax, which is a consumption tax and is included in the retail price of most goods. Currently, most of the rooms that are rented out like hotels, motels and rooms for rent are subject to a 5\% tax. Most goods and services sold and provided in Canada are subject to a 7\% national tax. In Montreal, Laval, Vancouver, British Columbia, St. John's, Newfoundland and Ontario, a 3\% hotel tax is charged. A tax increase from $4 \%$ to $7 \%$ is expected in Olas, Kansas. The collected taxes in Timmys are at the disposal of the hotel owners and are distributed quarterly by the subcommittee of the Corporate Economic Development Corporation (CERT) through a special account organized by the municipality. The revenues from the tourist tax are distributed according to the main directions of tourism development in the city in order to promote the marketing of the city as a tourist center and the future capital construction in it (Marinig).

The experience of developed countries undoubtedly shows that the provision of recreational services is extremely important for the development of the economy, and it is a topical and perspective issue of the coastal regions of Ukraine. Through the synergy of aquaculture and tourism, new quality of economic growth, social security, improving the well-being of citizens and positive financial, economic and socio-psychological effects can be ensured. In particular, the success of the development of recreation and the process of providing recreational services as a sphere of economic activity is determined in three main directions: economic, social and environmental. Economic success can be measured by the share of recreational services provided in the country's GDP, in terms of exports and in the number of jobs created. Social success is determined by employment, share of personal income from recreational services, etc. The environmental success of recreational services is linked to the application of general and area-specific environmental standards.

World experience proves that the recreational sphere naturally and harmoniously combines all opportunities 
ofglobal and national development of human and society on the basis of existing regional resources. Ukraine has significant potential for tourism development in the context of various destinations. Therefore, attracting investment in the tourism industry of the country should take on one of the most relevant values, since it will enable to attract more tourists and, accordingly, increase the volume of services provided. In general, the tourism industry in Ukraine has many imperfections in functioning, management and supervision, which require a separate, immediate and systemic solution.

\section{Conclusion}

The study shows that tourism has a leading place in the economies of the world leading countries and accounts for a significant share of GDP. But this is not the highest level. The number of tourists in the world is expected to increase by an average of 3.3 percent a year from 2010 to 2030. In absolute terms, international tourist arrivals will increase by approximately 43 million per year, compared to an average increase of 28 million per year from 1995 to 2010, reaching 1,400 million by 2020 and 1,800 million by 2030 (UNWTO 2014). Countries in regions with ocean or sea access must prepare for upgrading their infrastructure and facilities to cope with the significant increase, as coastal visitation is and will continue to trend.

Increasing the recreational potential of nature's coastal territories is one of the priorities of each country. Ensuring the development of artificial cultivation of bioresources and improvement of coastal infrastructure will allow not only to preserve the natural potential of the regions by optimizing the recreational load on natural systems, but also to increase the revenues of a certain area by expanding tourist services. At the same time, the formation of aquaculture tourism infrastructure will allow more full use of the recreational potential of the region's uniqueness, which will entail the development of a complex of related services in the fields of transport, hotel business, catering, sports, and trade.

The conducted research shows that demonstrative for Ukraine in the organization of provision of recreational services by municipal authorities in cities are: decentralization, delegation of powers to local authorities, establishment of organizational relations between subjects of recreational activity, local population, municipal authorities; creation of political, economic, environmental, institutional conditions for the functioning of recreational activities; introduction of incentive mechanisms for recreationists to constantly improve the quality of recreational services; strengthening the role of municipalities in planning, financing and organizing the provision of recreational services; improvement of the legal and methodological base for ensuring the functioning of the recreational services system, as well as creating organizational conditions for the development of recreational services, etc.

There are all the necessary prerequisites for the development of the recreational aquaculture services market in the Black Sea area of Ukraine. The market for these services is currently emerging and is in high demand (for example, the creation of several aqua farms). Analysis and forecast of aggregate demand in the tourist market showed that the number of tourists is increasing every year, and the tendency to increase tourist flow in the near future will continue. This is what makes the question of finding new ways of tourism development in Ukraine especially urgent.

\section{References:}

Pokolodna, M. M. (2012). Konspekt lektsij z dystsypliny "Rekreatsijni kompleksy svitu (v tomu chysli turresursy Ukrainy) [Lecture on the subject "recreational complex world (including tourist resources of Ukraine)]. Kharkiv: Kharkiv National Academy of Municipal Economy. (in Ukrainian)

Global Report on Food Tourism. World Tourism Organization (UNWTO), Madrid, Spain, 2012.

Mapped: Top Countries by Tourist Spending. Retrieved from: https://www.visualcapitalist.com/map-countriesby-tourist-spending/

Levtsov, S. V. (2015). Zarubizhnyy dosvid orhanizatsiyi nadannya rekreatsiynykh posluh ta yoho implementatsiya $v$ Ukrayini [Foreign experience of recreational service organization organizations and its implementation in Ukraine]. Dnipropetrovsk State Agrarian and Economic University. Retrieved from: http://www.dy.nayka.com.ua/ ?op=1\&z=889 Fishing \& Aquaculture. Retrieved from: https://www.theglobaleducationproject.org/earth/fisheries-and-aquaculture.php Global No.1 Business Data Platform. Retrieved from: https://www.statista.com/statistics/233223/travel-andtourism--total-economic-contribution-worldwide/

Viana, D. F., Halpern, B. S., \& Gaines, S. D. (2017). Accounting for tourism benefits in marine reserve design. Retrieved from: https://www.ncbi.nlm.nih.gov/pmc/articles/PMC5739484/

Marinig, K. Perspektivy nalogooblozheniya turizma na munitsipal'nom urovne (na primere goroda Timminsa) [Prospects for tourism taxation at the municipal level (on the example of the city of Timmins)]. Retrieved from: http://citystrategy.leontief.ru./world/marinig.htm (in Russian)

Stehnei, M. Irtyshcheva, I., Boiko, Y., Rogatina, L., \& Khaustova, K. (2018). Conceptual approaches to the formation of regional food security strategy in the context of sustainable development. Problems and Perspectives in Management, vol. 16(4), pp. 42-50. doi: http://dx.doi.org/10.21511/ppm.16(4).2018.04

Stehnei, M., Irtyshcheva, I., \& Gurina, O. (2018). Financial mechanism of the socio-oriented economic development of the black sea region. Baltic Journal of Economic Studies, vol. 4, no. 4, pp. 202-208. doi: 10.30525/2256-0742/2018-4-4-202-208 